\title{
Development, Internal and External Validation of Naproxen Sodium Sustained Release Formulation: an Level A In Vitro-In Vivo Correlation
}

\author{
Naproksen Sodyum Süreli Serbest Formülasyonun Geliştirilmesi, lç ve Dış \\ Olarak Doğrulaması: Bir Düzey A In Vitro-In Vivo Korelasyon
}

\author{
Ramesh NARAYANASAMY*, Ramakrishna SHABARAYA \\ Srinivas College of Pharmacy, Farengipete Post, Mangalore, Karnataka, India
}

\begin{abstract}
Objectives: The aim of the present study was to develop and validate an in vitro-in vivo correlation (IVIVC) for naproxen sodium-sustained release tablets and to compare their plasma concentrations over time with the immediate-release tablets.

Materials and Methods: In vitro release rate data were obtained for each tablet by using the USP Apparatus II, paddle stirrer at 50 rpm in pH 7.4 phosphate buffer. A four-way crossover study was conducted in 6 healthy subjects by administering naproxen sodium sustained release 375 $\mathrm{mg}$ and $500 \mathrm{mg}$ of immediate release tablets. Series of blood samples were collected over 24 hours and estimated by using the validated liquid chromatography tandem-mass spectrometry method.

Results: The similarity factor was calculated and it was found that values between, 50 and 100 indicates similarity of the profiles. Assessment of predicted and observed bioavailability was performed and prediction errors (PE) \% calculated, as per the Food Drug Administration guidelines, the average absolute PE\% of $C_{\max }$ and AUC of individual formulation was found below $15 \%$ for establishment of IVIVC, based on internal prediction strongly suggesting that the naproxen sodium IVIVC models are valid. During external validation the predicted curve for the naproxen sodium sustained-release tablets was found to be identical to immediate release tablets and considered as valid.

Conclusion: IVIVC can serve as a surrogate for in vivo bioavailability study and supports biowaivers, supports and validates the dissolution methods and specification settings and assists in quality control during scale-up and post-approval changes. It may be used to predict the variation in site change, process changes and to predict the absorption performance of naproxen sodium products with different release rates.

Key words: IVIVC, naproxen sodium, sustained release, dissolution, in vivo bioavailability study, internal and external predictability
\end{abstract}

öz

Amaç: Bu çalışmanın amacı, naproksen sodyumun sürekli salım tableti için in vitro-in vivo korelasyon (IVIVC) geliştirmek, doğrulamak ve zamana bağlı plazma konsantrasyonlarını derhal salınan tabletle karşılaştırmaktır.

Gereç ve Yöntemler: In vitro salım hızı verileri, pH 7.4 fosfat tampon içinde 50 dev/dakikada, USP Apparatus II, palet karıştırıcısı kullanılarak her bir tablet için elde edilmiştir. Naproksen sodium 375 mg sürekli salım ve 500 mg derhal salım tabletleri 6 sağlıklı kişiye uygulanarak dört yönlü bir çaprazlama çalıșması gerçekleștirilmiştir. Yirmi dört saat boyunca toplanan kan örnekleri valide edilmiş sıvı kromatografisi tandem-kütle spektrometresi yöntemi kullanılarak tayin edilmiştir.

Bulgular: Hesaplanan ve 50-100 arasında bulunan değerler benzerlik faktörlerini göstermektedir. $C_{\max }$ ve AUC ortalama değerlerine yakın bulunmuștur. Tahmin edilen ve gözlemlenen biyoyararlanım değerlendirmesi yapıldı ve Gıda İlaç İdaresi yönetmeliklerine göre \% tahmin hataları (PE) hesaplandı; iç tahmin ile IVIVC'nin oluşturulması için $\mathrm{C}_{\max }$ 'In ortalama mutlak \%PE'si ve formülasyonun bireysel formülasyonun AUC'si \%15'in altında bulundu, naproksen sodyumun IVIVC modelleri geçerlidir. Dış validasyon sırasında, naproksen sodyumun sürekli salım tableti için öngörülen eğri, derhal salım tableti ile aynı bulunması geçerli olduğunu göstermektedir.

Sonuç: Bu IVIVC, in vivo biyoyararlanım araştırması için vekil olarak hizmet edebilir ve biyolojik yönlendiricileri destekler, çözünme yöntemlerini ve spesifikasyon ayarlarını destekler ve onaylar, ölçek büyütme ve onay sonrası değişiklikler sırasında kalite kontrolünde yardımcı olur. Yer değişikliği, proses değişiklikleri ve farklı emisyon oranlarına sahip naproksen sodyum ürünlerinin emme performansını tahmin etmek için kullanılabilir.

Anahtar kelimeler: IVIVC, naproksen sodyum, sürekli salım, çözünme, in vivo biyoyararlanım çalışması, iç ve dış öngörülebilirlik

*Correspondence: E-mail: ramesh7779@gmail.com, Phone: 918242232700

Received: 12.12.2016, Accepted: 26.01.2017

๑Turk J Pharm Sci, Published by Galenos Publishing House. 


\section{INTRODUCTION}

In vitro-in vivo correction is a predictive mathematical model relating the relationship between an in vitro property of a dosage form and an in vivo response. ${ }^{5}$ In vitro-in vivo correlation (IVIVC) is most widely established by using formulations with different release rates i.e. slow, medium and fast, data on the in vitro release rates and in vivo plasma concentration-time profiles of developed formulations, and by using deconvolution techniques to confirm the link between dissolution rate and fraction absorbed. The Food Drug Administration (FDA) guidelines has discussed the three categories of IVIVC models: namely, level A, B, and C models. Level A is a linear is most widely used as it is developed point to point correlation and stands for in vitro and in vivo absorption rate of the drug. Level A can be developed on both deconvolution and convolution-based methods. Level $B$ compares the mean in vitro dissolution time to the mean in vivo residence time or the mean in vivo dissolution time. Level $\mathrm{C}$ is a single point comparison of dissolution time point to one pharmacokinetic parameter [e.g. $C_{\text {max }}$ area under the curve (AUC), and $T_{\max }$ time of the maximum plasma concentration]. Level $D$ is a rank order analysis. ${ }^{5}$ The development and validation of IVIVC is vital for optimization of sustained release dosage form as it predicts the in vivo release profile of the sustained release (SR) dosage form based on in vitro data. ${ }^{9}$

Various IVIVC studies have been published for a number of formulations, including Busprion, propranolol, nevirapine, metoprolol and other drugs. ${ }^{6-17}$ The concepts and methods used in establishing the IVIVC are reviewed elsewhere. ${ }^{4,5}$ According to BCS classification naproxen sodium comes under class 2 drug and in addition naproxen is relatively having a short life suggest suitable applicant for modified release formulation., ${ }^{1,2}$ The present work is intended to formulate naproxen sodium sustained release tablet, develop and validate the internal and external predictability of level A IVIVC models. In vitro dissolution study was performed to check the release profile and bioavailability study conducted to check the rate and extent of absorption of developed naproxen sodium sustained release and marketed immediate release tablet. Further established and validated IVIVC models can be used as a surrogate for the bioequivalence study, minimize the time and cost for manufacturers, a quality control tool to measure the product performance, a waiver for human studies when the minor changes are done as specified in the scale-up and post-approval changes (SUPAC)- immediate release and SUPAC-modified release guidance.

\section{MATERIALS AND METHODS}

\section{Chemicals and reagents}

Naproxen sodium, HPMC K100M supplied as a gift sample by Strides Arcolab Limited, Bangalore and Colorcon Asia Pvt. Limited, Goa, India. All other materials like talc, magnesium stearate, ethyl cellulose were procured from local dealer.

\section{In vitro dissolution study and data analysis}

The drug release profiles were examined by using by using the United States Pharmacopeia (USP) dissolution apparatus (type
2, paddle) $\mathrm{pH} 1.2,4.5,5.5,6.8$ and 7.4 at 50 \& 75 rpm (rotation per $\mathrm{min}$ ). The dissolution studies were performed on six tablet of naproxen sodium $375 \mathrm{mg}$ SR tablets (i.e. slow, medium and fast) and naproxen sodium $500 \mathrm{mg}$ tablet (marketed immediate release). Samples were drawn at 0.0, 0.5, 1.0, 1.5, 2.0, 3.0, 4.0, 6.0, 8.0, 12.0, 18.0 and 24.0 hours and analyzed by using UV spectroscopy at a wavelength of $332 \mathrm{~nm}$. The percentage fraction dissolved and percentage release at various time points were determined. The similarity of dissolution profiles were evaluated for fast versus slow, slow versus medium and medium versus fast by using the similarity factor (f2).

\section{In vivo bioavailability study and data analysis}

This was an single center, randomized, single-dose, openlabel, 4-way crossover, bioavailability study to compare the rate and extent of absorption of a naproxen sodium $375 \mathrm{mg} \mathrm{SR}$ tablets (i.e. slow, medium and fast) and naproxen sodium 500 mg tablet (marketed immediate release), in six healthy male subjects under fasting conditions. Samples were collected at 0.0, 0.5, 1.0, 1.5, 2.0, 2.5, 3.0, 3.5, 4.0, 4.5, 5.0, 5.5, 6.0, 8.0, $10.0,12.0,16.0$ and 24.0 hours post dose sample. A washout period of 7 days between the dosing of four periods. The study was approved by ethics committee and informed consent were provided by subjects prior enrolled into the study and. Validation of the method was carried out after the development of the liquid chromatography mass spectrometry (LCMS) methods. Validation performed as per the USFDA guidelines i.e. specificity/selectivity, carry over, linearity, precision and accuracy, recovery, dilution integrity, ruggedness, stabilities like freeze thaw stability, bench top stability, long term stability, stock solution stability. A simple and sensitive validated LCMS/ MS method used for estimation of plasma sample by using protein precipitate extraction. The calibration curves were linear in the range of $1.167 \mu \mathrm{g} / \mathrm{mL}$ to $163.729 \mu \mathrm{g} / \mathrm{mL}$ for naproxen sodium. Bioavailability study evaluated through plasma concentration data by using pharmacokinetic parameters like $C_{\text {max }}$ AUC, $T_{\text {max }}$, half lifeand estimation performed by using Phoenix 6.4.0 version software.

\section{IVIVC model development}

Linear regression analysis was used to study the relationship between the drug dissolved and the drug absorbed in percentage. A correlation was established for naproxen sodium $375 \mathrm{mg}$ SR tablets (i.e. slow, medium and fast) formulations $(M / F, S / F$, and $S / M)$. A linear regression done by using a least squares method to estimate the regression parameters. Determination coefficient $\left(r^{2}\right)$ was evaluated. The deconvolution procedure was used to obtain in vivo input profiles of naproxen sodium from the sustained release dosage forms. The percent of dissolved is plotted against the dissolution sampling points of target formulation to check whether developed IVIVC model is valid.

\section{IVIVC validation}

The objective is to predict the outcome of in vivo profile with a given model and target formulation of in vitro profile. Internal validation provides basis for the acceptability of the model and 
external validation is superior and gives the self-confidence in the model. As per the FDA guidance on IVIVC for level A criteria as follows: for internal validation the mean absolute percent prediction error i.e. for $\mathrm{C}_{\max }$ and $\mathrm{AUC}$ should not exceed $10 \%$, and for individual formulation should not exceed $15 \%$. For external validation the prediction errors i.e. $\mathrm{C}_{\max }$ and $\mathrm{AUC}$, for the formulation should not exceed $10 \%, 10 \%$ to $20 \%$ indicates in conclusive predictability and demonstrate the requirement for further study. The percent prediction errors (PE) for $\mathrm{C}_{\max }$ and AUC were calculated as follows:

$\% P E_{C_{\max }}=\left(\frac{C_{\max } \text { (observed) }-C_{\max } \text { (prediction) }}{C_{\max } \text { (observed) }}\right) \times 100$ (1)

$\% P E_{A \cup C}=\left(\frac{A U C \text { (observed) - AUC (prediction) }}{A U C \text { (observed) }}\right) \times 100(2)$

\section{RESULT AND DISCUSSION}

\section{In vitro dissolution study}

The in vitro dissolution studies were performed at different $\mathrm{pH}$ conditions (namely $\mathrm{pH} 1.2,4.5,5.5,6.8,7.4$ ) to select appropriate $\mathrm{pH}$ condition. The results of dissolution studies at different $\mathrm{pH}$ conditions with $50 \mathrm{rpm}$, at pH 1.2 and $50 \mathrm{rpm}$, drug release was partial and utmost $11 \%$ released from the formulations (F1F6; SR tablets composition are mentioned in Table 1) within 3 hours as shown in the Figure 1. At $\mathrm{pH} 4.5$, the drug release was very slow till 24 hours. The release was incomplete for all the formulations (F1-F6; SR tablets) as shown in the Figure 2. At $\mathrm{pH} 5.5$ homogeneous and slow release of drug from all the 6 formulations (F1-F6; SR tablets) over the period of $24 \mathrm{~h}$, $80.59-99.86 \%$ of drug was released as shown in the Figure 3. At $\mathrm{pH} 6.8$ and 7.4 about $86.79-97.32 \%$ as shown in the Figure 4 and $86.95-95.81 \%$ release of drug was observed as shown in the Figure 5 . Hence $\mathrm{pH} 5.5$ selected for in vitro dissolution studies for naproxen sodium. There is no significant changes observed in drug release when performed with $75 \mathrm{rpm}$. The in vitro drug release studies performed as per the USP method i.e.
$\mathrm{pH} 7.4 \mathrm{pH}$ condition at $50 \mathrm{rpm}$ for naproxen sodium SR tablets (i.e. F2 slow, F5 medium and F4 fast). The in vitro release characteristics of the fast, medium, and slow sustained release tablet of naproxen sodium were determined and presented in Figure 6. The similarity factor $\left(r^{2}\right)$ was calculated fast versus slow 52.52, fast versus medium 69.87 and medium versus slow 64.08 respectively. ${ }^{4}$

The percentage fraction dissolved for naproxen sodium are in the rank order of marketed immediate release, fast, medium and slow sustained release tablets and are presented in the Figure 6.

\section{In vivo bioavailability study and data analysis}

The mean pharmacokinetic profile for all formulations are presented in Table 2. The rank order release in the dissolution testing was obvious in the plasma concentration profile of

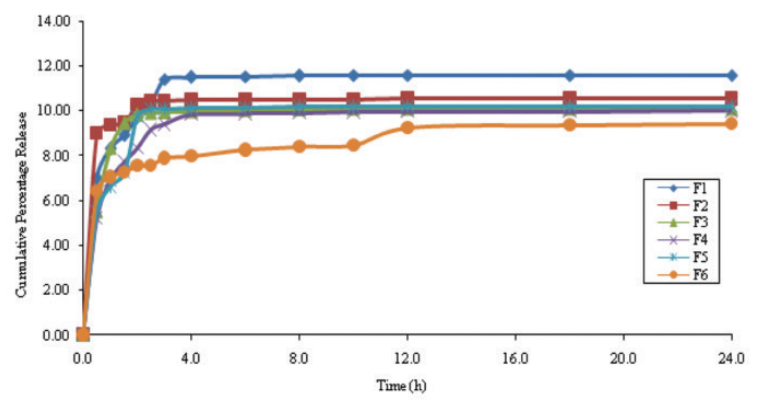

Figure 1. Percentage cumulative release profiles of naproxen sodium sustained release formulations (F1-F6) at pH 1.2 and $50 \mathrm{rpm}$

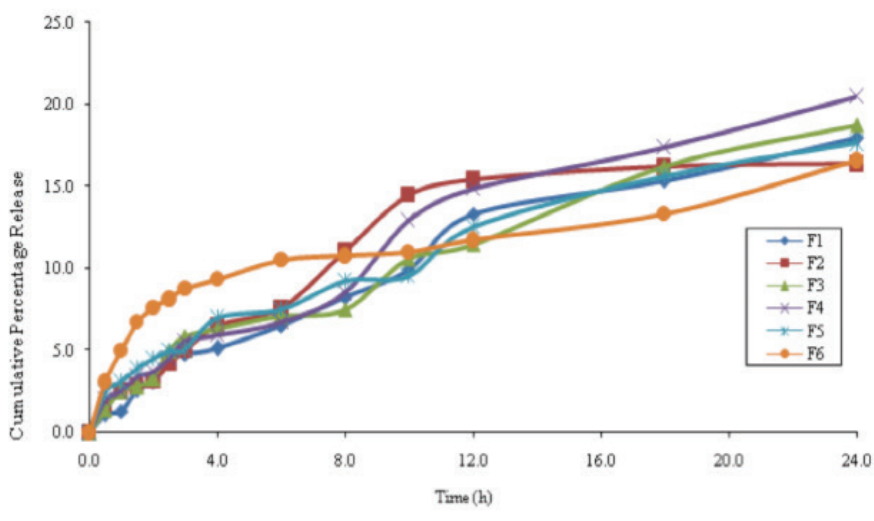

Figure 2. Percentage cumulative release profiles of naproxen sodium sustained release formulations (F1-F6) at pH 4.5 and $50 \mathrm{rpm}$

Table 1. Composition of naproxen sodium formulation (F1-F6)

\begin{tabular}{llllllll} 
Formulation & Naproxen sodium & HPMC K100M & Talc (1.5\%) & Magnesium stearate (1.5\%) & Talc (1\%) & Magnesium stearate (1\%) & Ethyl cellulose \\
\hline F1 & 375 & $75 \mathrm{mg}$ & - & - & $4.50 \mathrm{mg}$ & $4.50 \mathrm{mg}$ & - \\
\hline F2 & 375 & $150 \mathrm{mg}$ & - & - & $5.25 \mathrm{mg}$ & $6.00 \mathrm{mg}$ & - \\
\hline F3 & 375 & $225 \mathrm{mg}$ & - & - & $5.25 \mathrm{mg}$ & $6.00 \mathrm{mg}$ & - \\
\hline F4 & 375 & $37.5 \mathrm{mg}$ & $6.75 \mathrm{mg}$ & $6.75 \mathrm{mg}$ & - & - & $37.5 \mathrm{mg}$ \\
\hline F5 & 375 & $37.5 \mathrm{mg}$ & $7.87 \mathrm{mg}$ & $7.87 \mathrm{mg}$ & - & - & $37.5 \mathrm{mg}$ \\
\hline F6 & 375 & $37.5 \mathrm{mg}$ & $9.00 \mathrm{mg}$ & $9.00 \mathrm{mg}$ & - & - & $37.5 \mathrm{mg}$ \\
\hline
\end{tabular}




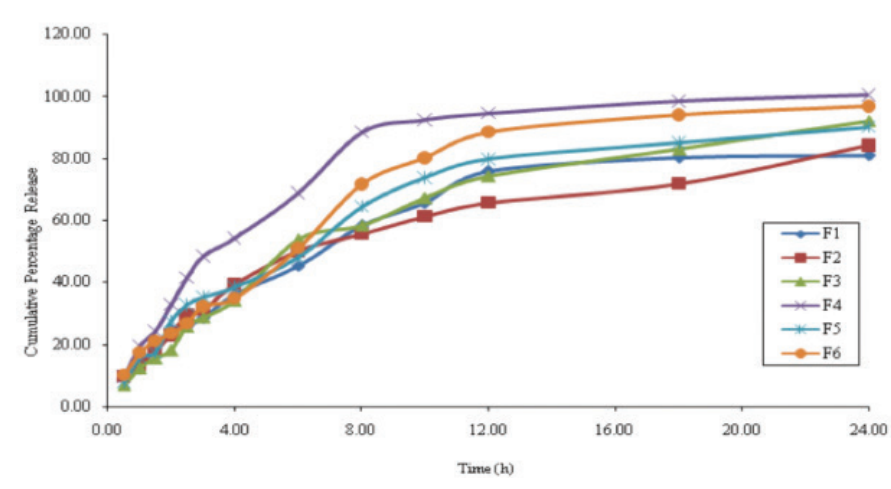

Figure 3. Percentage cumulative release profiles of naproxen sodium sustained release formulations (F1-F6) at $\mathrm{pH} 5.5$ and $50 \mathrm{rpm}$

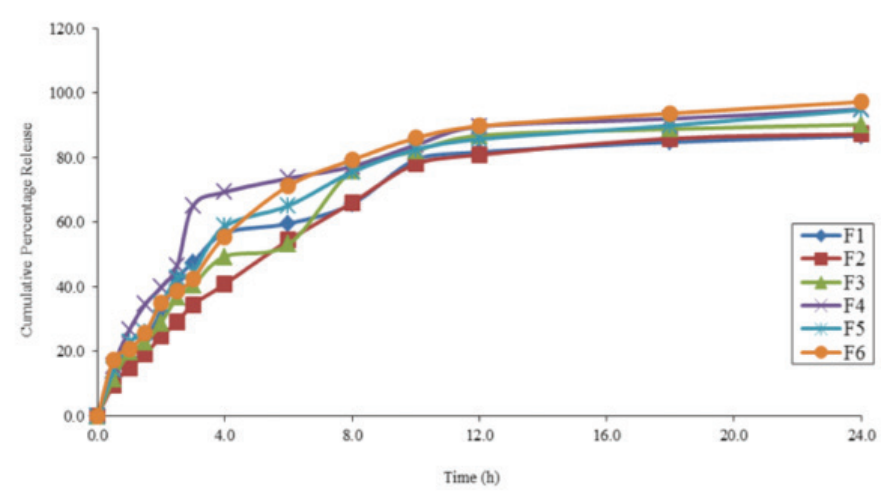

Figure 4. Percentage cumulative release profiles of naproxen sodium sustained release formulations (F1-F6) at $\mathrm{pH} 6.8$ and $50 \mathrm{rpm}$

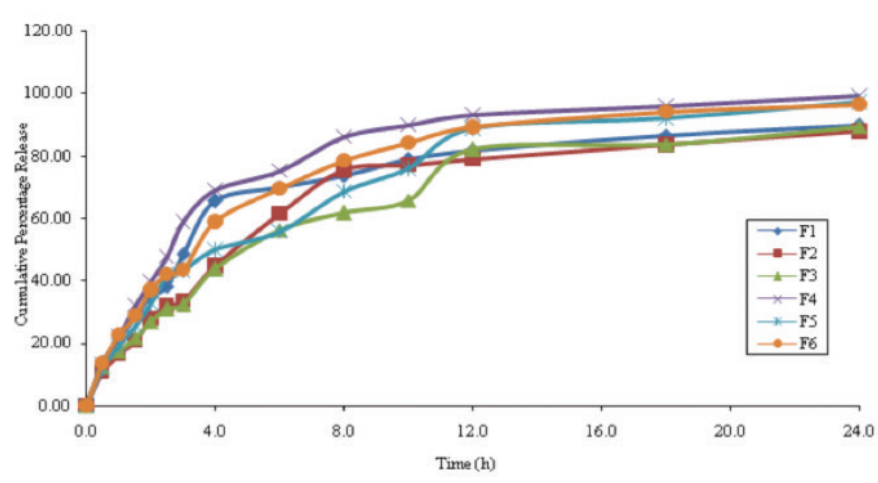

Figure 5. Percentage cumulative release profiles of naproxen sodium sustained release formulations (F1-F6) at $\mathrm{pH} 7.4$ and $50 \mathrm{rpm}$ naproxen sodium as in the Figure 7. AUC of naproxen slow release and medium release tablet was significantly higher compare to immediate release and fast release tablet. There is significant difference observed in naproxen slow and medium sustained release tablet compare to marketed immediate release and fast sustained tablet. AUC of naproxen sustained release tablets was much higher than immediate release tablet, may due to change in location of naproxen sodium absorption in gastrointestinal tract.

\section{In vitro-in vivo correlation development}

Level $A$ in vitro and in vivo correlation was developed by comparing percent dissolved versus the percent absorbed of naproxen sodium fast, medium and slow sustained release and marketed immediate release tablets. The IVIVC plot was constructed using percentage of drug dissolved at $\mathrm{pH} 7.4$

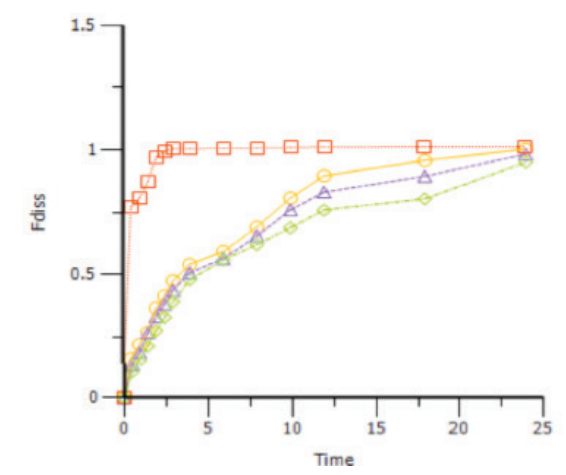

Fdiss vs Time - Fast -.- Medium -. Reference

Figure 6. Percentage fraction dissolved versus time for naproxen sodium IR tablet and SR tablets (i.e. F2 slow, F5 medium and F4 fast)

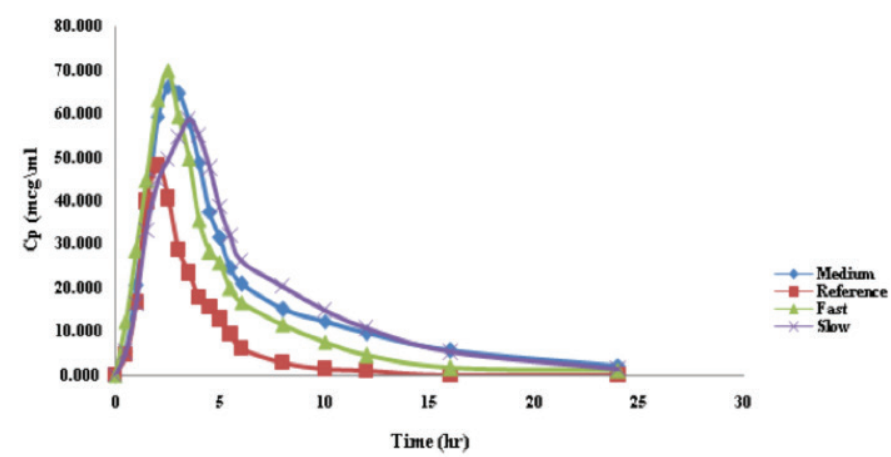

Figure 7. Mean plasma concentrations versus time of naproxen sodium for marketed immediate release and sustained release tablet (fast, medium and slow)

Table 2. Mean pharmacokinetic parameter of naproxen sodium for marketed immediate release and sustained release tablet (fast, medium and slow)

\begin{tabular}{llll} 
Formulation & $\mathrm{T}_{\max }(\mathrm{hr})$ & $\mathrm{C}_{\max }(\mathrm{ug} / \mathrm{mL})$ & $\mathrm{AUC}\left(\mathrm{hr}{ }^{*} \mathrm{ug} / \mathrm{mL}\right)$ \\
\hline Immediate release tablet & $1.833 \pm 0.258$ & $54.209 \pm 10.685$ & $147.483 \pm 36.265$ \\
\hline Fast sustained release tablet & $2.167 \pm 0.258$ & $73.767 \pm 4.889$ & $307.561 \pm 7.775$ \\
\hline Medium sustained release tablet & $2.667 \pm 0.258$ & $68.879 \pm 4.562$ & $391.273 \pm 82.259$ \\
\hline Slow sustained release tablet & $3.583 \pm 0.376$ & $63.199 \pm 3.141$ & $391.499 \pm 69.217$ \\
\hline
\end{tabular}

AUC: Area under the curve 
buffer dissolution media at $50 \mathrm{rpm}$ versus the percentage of drug absorbed. The slope of the best-fit line was examined using linear regression analysis and coefficient of correlation $\left(r^{2}\right)$. IVIVC model linear regression of percentage dissolved and percentage absorbed for naproxen sodium sustained release tablet presented in the Figure 8-10. The correlation coefficient $\left(r^{2}\right)$ for naproxen sodium SR tablets medium versus slow was

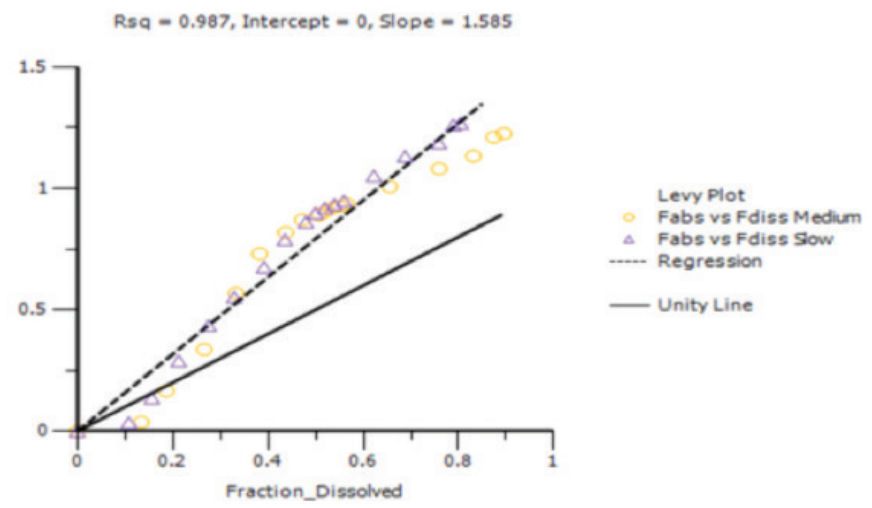

Figure 8. In vitro-in vivo correlation model linear regression percentage dissolved and percentage absorbed for naproxen sodium medium and slow sustained release tablet

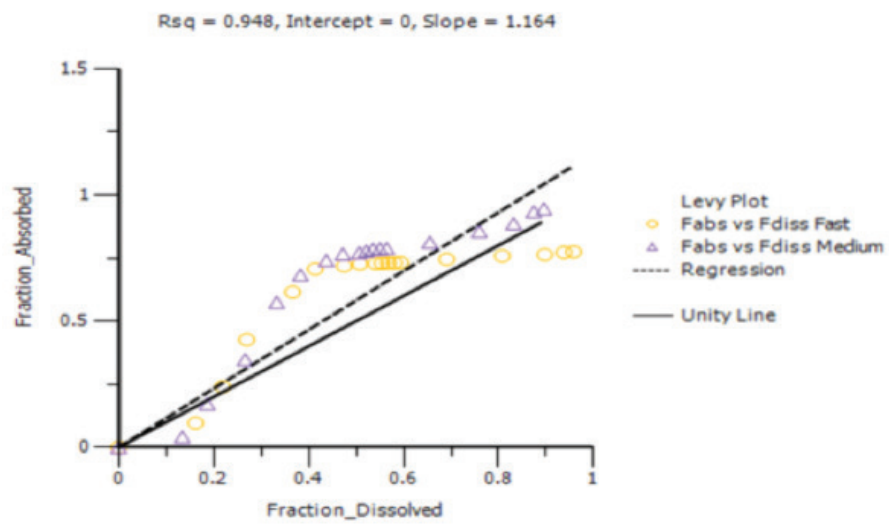

Figure 9. In vitro-in vivo correlation model linear regression percentage dissolved and percentage absorbed for naproxen sodium fast and medium sustained release tablet

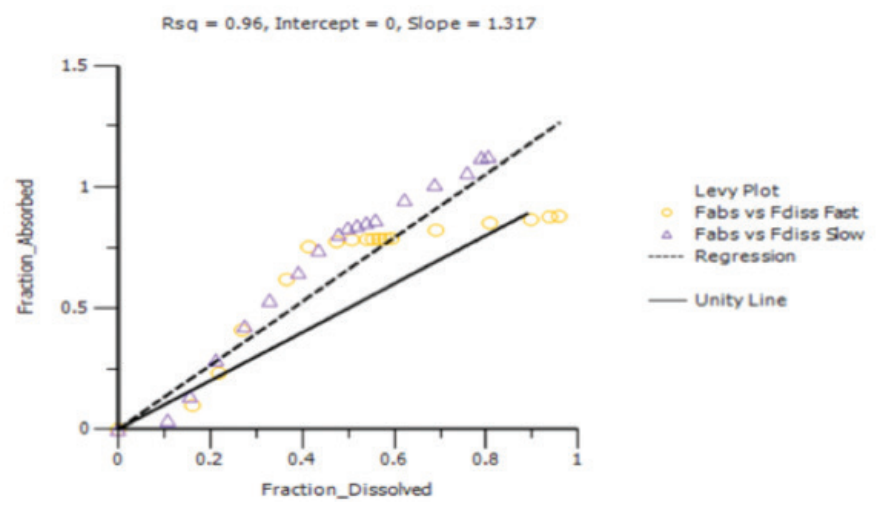

Figure 10. In vitro-in vivo correlation model linear regression percentage dissolved and percentage absorbed for naproxen sodium fast and slow sustained release tablet
0.987, fast versus medium was 0.948 , and naproxen sodium SR tablets fast versus medium was 0.96 respectively. Good linear regression relationship observed between all the three test formulation. Edington et al.9 described the dissolution methodology which discriminates between the formulation and mimics the in vivo release profile in development of IVIVC.

\section{IVIVC validation}

The internal validation of the IVIVC was examined by using the mean in vitro dissolution data and mean in vivo pharmacokinetics of the naproxen sodium sustained release tablets (i.e. slow, medium fast) corresponds to fast/medium/slow SR tablets. Each of IVIVC model predicted naproxen sodium plasma concentration versus time profiles were compared to the experimental data using prediction error metrics. The observed plasma concentration of naproxen sodium sustained release tablets (i.e. slow, medium and fast) are presented in the Figure 11-13, good correlation found between the observed and predicted plasma concentration.

\section{Internal validation}

The validity of correlation assessed by determining how well the IVIVC model predict the rate and extent of naproxen sodium as characterized by $\mathrm{C}_{\text {max }}$ (maximum plasma concentration) and AUC (area under the plasma concentration-time curve from time zero to the time of the last quantifiable concentration). The prediction error estimated by using naproxen sodium slow SR tablets as a target formulation refer the Table 3. $C_{\max }$ and AUC were found close to the mean values. The prediction error estimated by using naproxen sodium fast sustained release tablets as a target formulation refer the Table $4 . C_{\max }$ and AUC were found close to the mean values. The prediction error estimated by using naproxen sodium medium sustained release tablets as a target formulation refer the Table $5 . C_{\operatorname{mavx}}$ and AUC were found close to the mean values. As per the FDA for IVIVC the average absolute prediction error should be $10 \%$ and in addition individual formulation should not exceed $15 \%$. In the present study relatively low prediction error for $\mathrm{C}_{\max }$ and $A U C$ observed strongly suggest that the naproxen sodium IVIVC models are valid. Cross validation between the naproxen sodium sustained release tablets showed well within

Table 3. Prediction errors (\%) associated with $\mathrm{C}_{\max }$ and AUC for naproxen sodium fast vs. slow sustained release tablets

\begin{tabular}{lll} 
Formulation & Parameter & PE\% \\
\hline Fast & AUC & 4.852 \\
\hline Fast & $C_{\max }$ & -21.187 \\
\hline Medium & AUC & 0.794 \\
\hline Medium & $C_{\max }$ & -26.879 \\
\hline Slow & AUC & -5.643 \\
\hline Slow & $C_{\max }$ & -33.069 \\
\hline
\end{tabular}

AUC: Area under the curve, PE: Prediction errors 
the acceptance limits and provides the self confidence to next stage of validation.

\section{External validation}

IVIVC for naproxen sodium immediate release tablet was used as a target formulation to predict the plasma concentration of

Table 4. Prediction errors (\%) associated with $\mathrm{C}_{\max }$ and AUC for naproxen sodium fast vs. medium sustained release tablets

\begin{tabular}{lll} 
Formulation & Parameter & PE\% \\
\hline Fast & AUC & -18.760 \\
\hline Fast & $C_{\max }$ & -35.896 \\
\hline Medium & AUC & 14.180 \\
\hline Medium & $C_{\max }$ & -40.250 \\
\hline Slow & AUC & 6.8779 \\
\hline Slow & $C_{\max }$ & -44.696 \\
\hline
\end{tabular}

AUC: Area under the curve, PE: Prediction errors

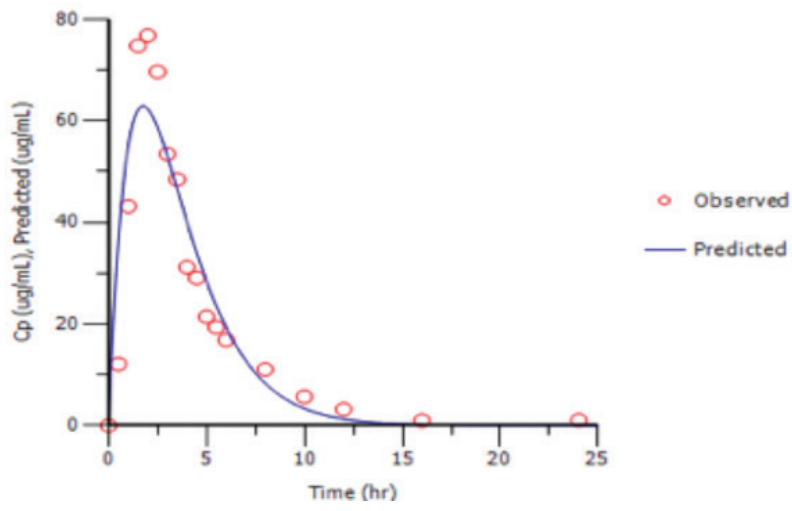

Figure 11. Observed and predicted plasma concentration for naproxen sodium fast sustained release tablet

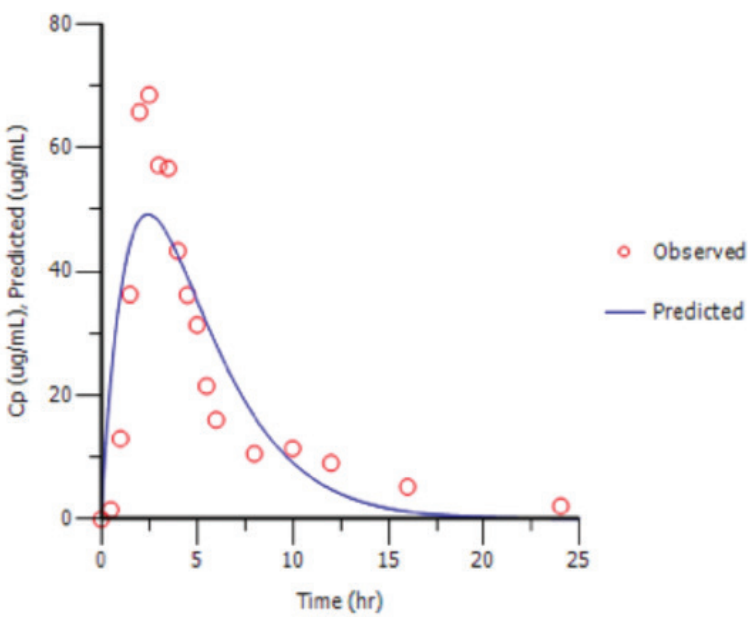

Figure 12. Observed and predicted plasma concentration for naproxen sodium medium sustained release tablet naproxen sodium sustained release tablets (i.e. slow, medium and fast). Figure 14-16 shows the plasma concentration versus time of predicted formulation (immediate release tablet) with naproxen sodium fast, medium and slow SR tablet. The predicted curve for the naproxen sodium SR tablets (i.e. slow, medium and fast) are identical to immediate release tablet and considered model is valid.

Table 5. Prediction errors (\%) associated with $C_{\max }$ and AUC for naproxen sodium medium vs. slow sustained release tablets

\begin{tabular}{lll} 
Formulation & Parameter & PE\% \\
\hline Fast & AUC & -5.852 \\
\hline Fast & $C_{\max }$ & -31.281 \\
\hline Medium & AUC & -9.495 \\
\hline Medium & $C_{\max }$ & -35.501 \\
\hline Slow & AUC & -15.271 \\
\hline Slow & $C_{\max }$ & -39.791
\end{tabular}

AUC: Area under the curve, PE: Prediction errors

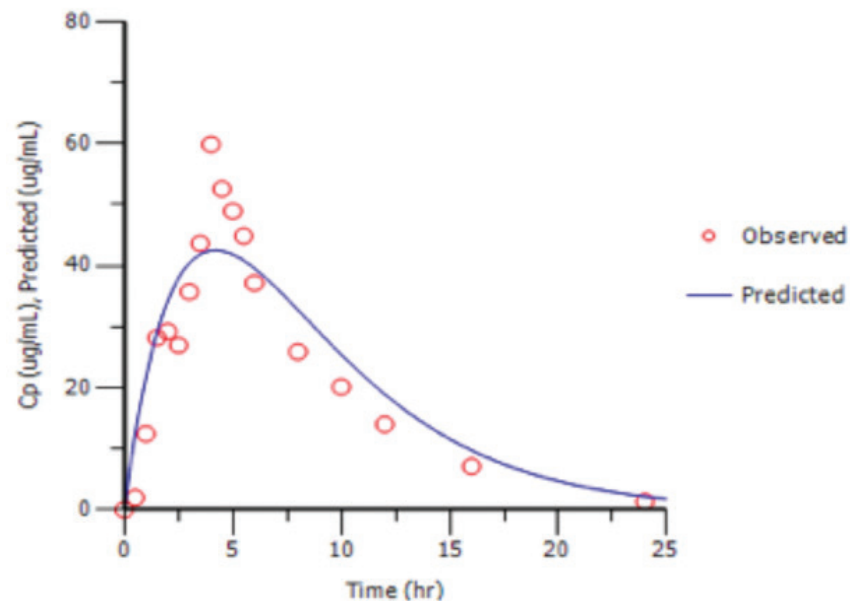

Figure 13. Observed and predicted plasma concentration for naproxen sodium slow sustained release tablet

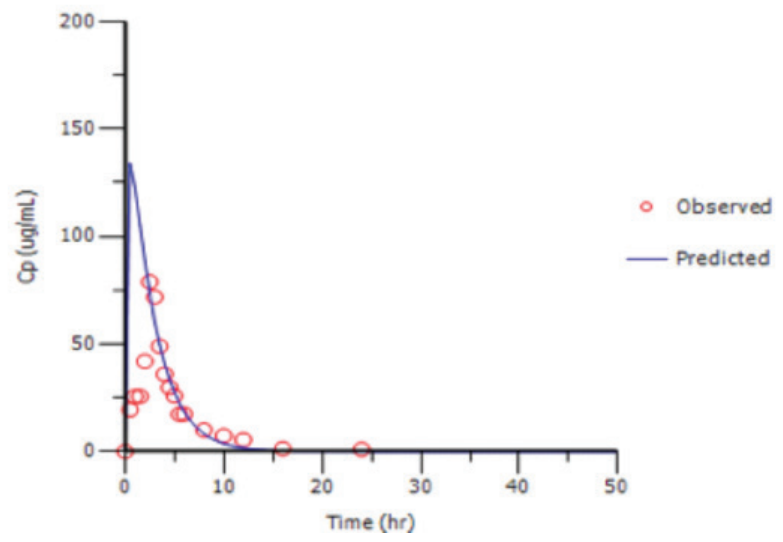

Figure 14. Plot of plasma concentration versus time of predicted formulation with naproxen sodium fast sustained release tablet 


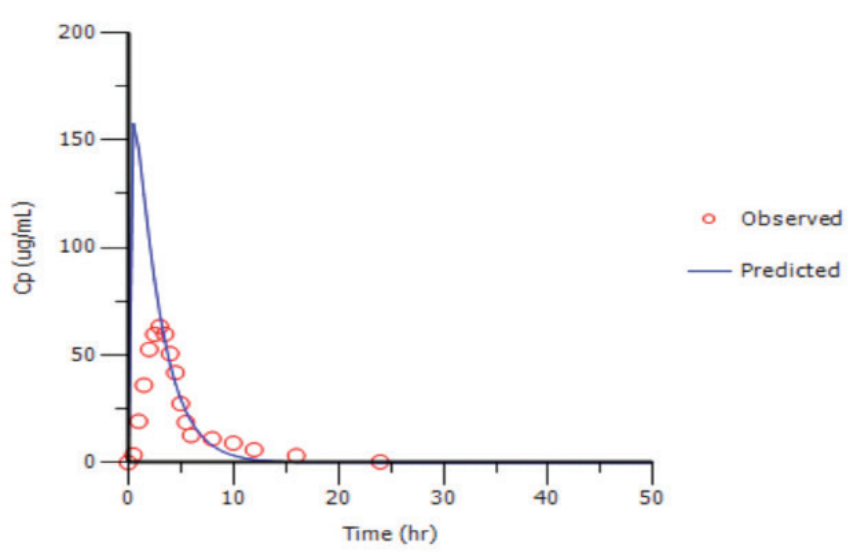

Figure 15. Plot of plasma concentration versus time of predicted formulation with naproxen sodium slow sustained release tablet

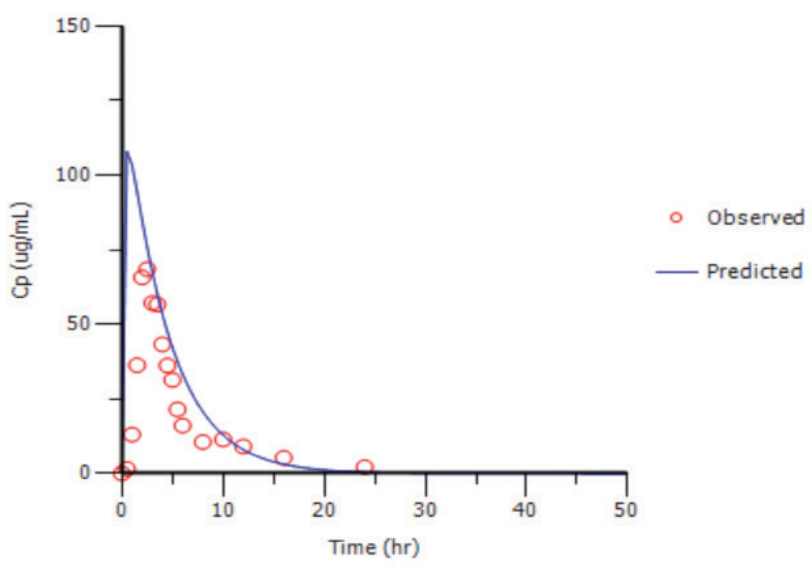

Figure 16. Plot of plasma concentration versus time of predicted formulation with naproxen sodium medium sustained release tablet

\section{CONCLUSION}

This study established and validated the internal and external predictability of an IVIVC relationship for naproxen sodium formulation. Meaningful relationship was observed between the in vitro and in vivo parameters, thus indicates an exceptional IVIVC model for naproxen sodium SR tablets (i.e. slow, medium and fast). The resulted prediction errors are within the acceptance limit as per the USFDA guidelines for both $\mathrm{C}_{\text {max }}$ and AUC. It can support dissolution data to predict the in vivo absorption, act as a biowaiver for bioequivalence and bioavailability studies and serve as a model for evaluating the naproxen sodium sustained release formulation. It can supports and validates the use of dissolution methods and specification settings, assisting in quality control which will be supportive for SUPAC.

\section{ACKNOWLEDGEMENTS}

The authors gratefully acknowledge administration of Srinivas College of Pharmacy, SeQuent Research Limited \& Strides Arcolab Ltd, Colorcon Asia Pvt Limited, India and Phoenix Winonlin Certara software Hyderabad, India for granting support to carry out the work.
Conflict of Interest: No conflict of interest was declared by the authors.

\section{REFERENCES}

1. De Haan P, Lerk CF. Oral controlled release dosage forms. A review. Pharm Weekbl Sci. 1984;6:57-67.

2. Rashid HO, Kabir AKL, Hossaina Z, Rouf ASS. Design and Formulation of Once Daily Naproxen Sustained Release Tablet Matrix from Methocel K 15M CR and Methocel K 100M CR. Iranian Journal of Pharmaceutical Sciences Autumn. 2009:5:215-224.

3. Yasmin D, Rahman R, Akter M. Formulation development of directly compressed Naproxen SR tablet using Kollidon SR and Avicel PH 102 polymer. International Current Pharmaceutical Journal. 2013;2:112-114.

4. Huntjens DR, Spalding DJ, Danhof M, Della Pasqua OE. Correlation between in vitro and in vivo concentration-effect relationships of naproxen in rats and healthy volunteers. Br J Pharmacol. 2006;148:396-404.

5. Extended Release Oral Dosage Forms: Development, Evaluation, and Application of In Vitro/In Vivo Correlations. U.S. Department of Health and Human Services Food and Drug Administration Center for Drug Evaluation and Research (CDER) September 1997 BP 2. http://www.fda. gov/cder/guidance/index.htm.

6. Takka S, Sakr A, Goldberg A. Development and validation of an in vitro-in vivo correlation for buspirone hydrochloride extended release tablets. J Control Release. 2003;88:147-157.

7. Huang YB, Tsai YH, Yang WC, Chang JS, Wu PC, Takayama K. Once-daily propranolol extended-release tablet dosage form: formulation design and in vitro/in vivo investigation. Eur J Pharm Biopharm. 2004;58:607-614.

8. Macha S, Yong CL, Darrington T, Davis MS, MacGregor TR, Castles $\mathrm{M}$, Krill SL. In vitro-in vivo correlation for nevirapine extended release tablets. Biopharm Drug Dispos. 2009;30:542-550.

9. Edington ND, Marroum P, Uppoor R, Hussain A, Augsburger L. Development and internal validation of an in vitro-in vivo correlation for a hydrophilic metoprolol extended release tablet formulation. Pharm Res. 1998;15:466-473.

10. Sankalia JM, Sankalia MG, Mashru RC. Drug release and swelling kinetics of directly compressed glipizide sustained release matrices: establishment of level A IVIVC. J Control Release. 2008;129:49-58.

11. Dutta S, Qiu Y, Samara E, Cao G, Granneman GR. Once a day extended release dosage form of divalproex sodium III: development and validation of a level A in vitro-in vivo Correlation. J Pharm Sci. 2005;94:1949-1956.

12. Li ZQ, He X, Gao X, Xu YY, Wang YF, Gu H, Ji RF, Sun SJ. Study on dissolution and absorption of four dosage forms of isosorbide mononitrate: level A in vitro-in vivo correlation. Eur J Pharm Biopharm. 2011;79:364-371.

13. Frick $A$, Möller $H$, Wirbitzki E. Biopharmaceutical characterization of oral controlled modified-release drug products. In vitro/in vivo correlation of roxatidine. Eur J Pharm Biopharm. 1998;46:313-319.

14. Dalton JT, Straughn AB, Dickason DA, Grandolfi GP. Predictive ability of level $A$ in vitro-in vivo correlation for ringcap controlled-release acetaminophen tablets. Pharm Res. 2001;18:1729-1734.

15. Qiu Y, Gupta P, Briskin J, Cheskin H, Semla S. Sustained-release multiparticulate formulations of Zileuton. I. In vitro and in vivo evaluation. Intional Journal of Pharmaceutics. 1996;143:179-185.

16. Qui Y, Cheskin H, Briskin J, Engh K. Sustained-release hydrophilic matrix tablets of zileuton: formulation and in vitro/in vivo studies. J Contrl Rel. 1997;45:249-256.

17. Mandal U, Ray KK, Gowda V, Ghosh A, Pal TK. In-vitro and in-vivo correlation for two gliclazide extended-release tablets. J Pharm Pharmacol. 2007;59:971-976.

18. Balan G, Timmins P, Greene DS, Marathe PH. In-vitro in-vivo correlation models for glibenclamide after administration of metformin/glibenclamide tablets to healthy human volunteers. J Pharm Pharmacol. 2000;52:831-838. 